Research Article

www.jestr.org

\title{
Performance of Different Acids on Sandstone Formations
}

\author{
M. A. Zaman", Md. M. Alam, and Md. Abdul Matin.
}

Dep. of Petroleum Engineering, Universiti Teknologi PETRONAS, Malaysia.

Received 9 April 2013; Accepted 17 December 2013

\begin{abstract}
Stimulation of sandstone formations is a challenging task, which involves several chemicals and physical interactions of the acid with the formation. Some of these reactions may result in formation damage. Mud acid has been successfully used to stimulate sandstone reservoirs for a number of years. It is a mixture of hydrofluoric (HF) and hydrochloric $(\mathrm{HCl})$ acids designed to dissolve clays and siliceous fines accumulated in the near-wellbore region. Matrix acidizing may also be used to increase formation permeability in undamaged wells. The change may be up to $50 \%$ to $100 \%$ with the mud acid.

For any acidizing process, the selection of acid (Formulation and Concentration) and the design (Pre-flush, Main Acid, After-flush) is very important. Different researchers are using different combinations of acids with different concentrations to get the best results for acidization. Mainly the common practice is combination of Hydrochloric Acid Hydrofluoric with Concentration ( $3 \% \mathrm{HF}-12 \% \mathrm{HCl})$.

This paper presents the results of a laboratory investigation of Orthophosphoric acid instead of hydrochloric acid in one combination and the second combination is Fluoboric and formic acid and the third one is formic and hydrofluoric acid. The results are compared with the mud acid and the results calculated are porosity, permeability, and FESEM Analysis and Strength tests. All of these new combinations shows that these have the potential to be used as acidizing acids on sandstone formations.
\end{abstract}

Keywords: Sandstone, Mud Acid, Stimulation, Acidizing, Undamaged wells.

\section{Introduction}

The number of different acids are used in conventional acidizing treatments, the most common are: Hydrochloric, $\mathrm{HCl}$, Hydrofluoric, $\mathrm{HF}$, Acetic, $\mathrm{CH}_{3} \mathrm{COOH}$, Formic, $\mathrm{HCOOH}$.

Typically, sandstone matrix stimulation involves three stages [2]:

1.1. A pre flush stage to dissolve any carbonates that may be present and to displace the connate water from the rock.

1.2. A mud acid treatment to dissolve siliceous and damaging material.

1.3. An after flush to restore wettability and provide rapid formation cleanup.

\section{A. Productivity Improvement:}

Productivity Improvement is the process of increasing production from oil or gas wells by removing flow restrictions that exists near the wellbore. Generally the types of productivity impairment which can be removed by acidization are:

1.A.1. Near well-bore formation damage (Can be solved

*E-mail address: umer.engr@hotmail.com ISSN: 1791-2377 @ 2011 Kavala Institute of Technology. All rights reserved. by matrix acidization).

1.A.2. Poor reservoir permeability (Can be solved by matrix acidization as well as fracturing) [1].

\section{B. Sandstone Acidizing:}

Sandstone is primarily composed of Silica and Silicate minerals, including quartz, various forms of clays, feldspars and in rare cases zeolites. Sandstone Acidizing is used to stimulate the true permeability of sandstone formations. The fluids are pumped into the porosity of the rock at below the fracturing pressure and the acid reacts with a large portion of the formation. In sandstone acidization many reactions take place; the most important of them are the reactions of $\mathrm{HCl}$ and HF with carbonates, the reactions of HF with silicates, Quartz and feldspar. Hydrofluoric reactivity with the silica makes it unique in sandstone acidizing application. Other acids such as hydrochloric, nitric and sulphuric acids are unreactive with silica. [4]

$4 \mathrm{HF}+\mathrm{SiO}_{2} \longrightarrow \mathrm{T} \mathrm{SiF}_{4}+2 \mathrm{H}_{2} \mathrm{O}$

As HF enters a sandstone core, almost all the minerals present begin to dissolve, but at different rates depending on the intrinsic rates of heterogeneous reactions and the exposed surface areas. The reacting minerals can be divided into two distinct categories: slow and fast reacting. Quartz tends to act at a slower rate whereas feldspars, clays tend to react at a faster rate [5] - [7]. 


\section{Matrix Acidizing:}

Matrix acidizing involves the use of acid injected at below fracture pressure. It is normally used for the removal of skin damage associated with work-over, well killing or injection fluids, and by precipitation of scale deposits in tubular, the wellbore or within the formation.

Matrix acidizing may also be used to increase formation permeability in undamaged wells. Where damage is thought to exist within the formation, the aim of the treatment is to achieve more or less radial acid penetration deep into the formation to increase the formation permeability around the wellbore. There is a practical limit of about a $50 \%$ increase in injectivity or productivity of undamaged oil or water wells which can be achieved using matrix stimulation. [9]

\section{Experimental Work}

- The core samples used having permeability less than $100 \mathrm{md}$ as matrix acidizing is done to increase the permeability, if permeability is already high then matrix acidizing is not done. Acidizing has been performed with different concentrations of $(\mathrm{HO})_{2} \mathrm{HPO} / \mathrm{HF}, \mathrm{HBF}_{4}$ / $\mathrm{HCOOH}, \mathrm{HF} / \mathrm{HCOOH}$ and $\mathrm{HF} / \mathrm{HCl}$.

- For the purpose of acidizing, we have to do the saturation of the core sample for some time under vacuum conditions to speed up the process.

- Desiccators are used in order to create the vacuum and saturation time is 4 hours to ensure that maximum acid should enter into the core sample.

- The core is dried before and after the acidizing process for 24 hours at $80^{\circ} \mathrm{C}$. The size of the core is 3 inch in length and 1.5 inch in Diameter. The total volume used is $175 \mathrm{ml}$ which includes both acids and distilled water.

\section{ACID Volume CALCULATIONS:}

Acid volume calculations have been made using the formula:

$$
\mathbf{M}_{1} \mathbf{V}_{1}=M_{2} \mathbf{V}_{2}
$$

Concentration of acids is already provided by supplier: $\mathrm{HCl}$ is $37 \%, \mathrm{HF}$ is $48 \%, \mathrm{HBF}_{4}$ is $50 \%, \mathrm{HCOOH}$ is $100 \%$ and $\mathrm{H}_{3} \mathrm{PO}_{4}$ is $100 \%$

For Example: If combination is $3 \% \mathrm{HF}: 12 \% \mathrm{HCl}$, the calculations are as follows:

$$
\begin{array}{ll}
\text { For HCl } & \text { For HF } \\
\mathrm{M}_{1} \mathrm{~V}_{1}=\mathrm{M}_{2} \mathrm{~V}_{2} & \mathrm{M}_{1} \mathrm{~V}_{1}=\mathrm{M}_{2} \mathrm{~V}_{2} \\
(37) \mathrm{V}_{1}=(12)(175) & (48) \mathrm{V}_{1}=(3)(175) \\
\mathrm{V}_{1}=\mathbf{5 6 . 7 5} \mathbf{~ m l} & \mathrm{V}_{1}=\mathbf{1 0 . 7 5} \mathbf{~ m l}
\end{array}
$$

As, there is one liter of solution, the remaining volume will be filled in by the distilled water. Volume of water $=$ $175-56.75-10.75=107.5 \mathbf{~ m l}$

\section{Saturation of Core Sample:}

- $\quad$ Prepare the desiccators and vacuum pump.

- Immerse the sample in $175 \mathrm{ml}$ of acid solution.

- Place the lid on the desiccators and open the tap and cover with appropriate sized safety cage.

- Connect the tap to the vacuum pump and open the tap slowly to evacuate the desiccators.

- After the samples had been dried, close the tap and disconnect the vacuum supply.
- Repeat the entire step by using all the acid solutions on core samples.

- Measure permeability, porosity, minerology and strength of the samples before and after the acidizing.

\section{Results and Discussion}

\section{A. Porosity Calculations:}

\section{Analysis:}

- From the table \# 1, it is clear that the porosity increase with the new acid combination HF: $\mathrm{H}_{3} \mathrm{PO}_{4}$ is more as compared to mud acid. The maximum increase is with $3 \% \mathrm{HF}: 9 \% \mathrm{H}_{3} \mathrm{PO}_{4}$ which is almost $100 \%$ and $1.5 \% \mathrm{HF}$ : $9 \% \mathrm{H}_{3} \mathrm{PO}_{4}$ also shows good results as compare to other combinations. But in this combination if the concentration of $\mathrm{H}_{3} \mathrm{PO}_{4}$ is increased then the change in the porosity decreased.

- The other combination showing reasonable result is $\mathrm{HBF}_{4} \mathrm{HCOOH}$. From results it is clear that the change with the combination of $\mathrm{HBF}_{4}$ : $\mathrm{HCOOH}$ with each concentration is almost same. Each combination shows good results and there is not much difference with the change in the concentrations of the acids.

- The combination HF: HCOOH show reasonable results. Although the percentage change is better than mud acid but it is not better than the last combination discussed. The same is the case with the $\mathrm{HBF}_{4} \mathrm{HCOOH}$, in all

\begin{tabular}{|c|c|c|c|c|c|}
\hline Combination used & $\begin{array}{l}\text { Initial } \\
\text { Porosity }\end{array}$ & $\begin{array}{l}\text { Final } \\
\text { Porosity }\end{array}$ & $\begin{array}{l}\text { \%age } \\
\text { change }\end{array}$ & $\begin{array}{l}\text { Final } \\
\text { Porosity } \\
\text { (After } \\
\text { flush) }\end{array}$ & $\begin{array}{l}\text { \%age } \\
\text { change }\end{array}$ \\
\hline $3 \% \mathrm{HF}: 12 \% \mathrm{HCl}$ & 10.28 & 15.12 & $47.08 \%$ & 16.85 & $63.91 \%$ \\
\hline $3 \% \mathrm{HF}: 12 \% \mathrm{HCOOH}$ & 10.11 & 14.22 & $40.65 \%$ & 16.79 & $66.07 \%$ \\
\hline $3 \% \mathrm{HF}: 9 \% \mathrm{HCOOH}$ & 10.98 & 16.5 & $50.27 \%$ & 18.2 & $65.76 \%$ \\
\hline $1.5 \% \mathrm{HF}: 9 \% \mathrm{HCOOH}$ & 10.52 & 16.17 & $53.71 \%$ & 18.02 & $71.29 \%$ \\
\hline $3 \% \mathrm{HF}: 12 \% \mathrm{H}_{3} \mathrm{PO}_{4}$ & 9.89 & 14.319 & $44.78 \%$ & 15.23 & $53.99 \%$ \\
\hline $3 \% \mathrm{HF}: 9 \% \mathrm{H}_{3} \mathrm{PO}_{4}$ & 9.17 & 16.11 & $75.68 \%$ & 18.10 & $97.38 \%$ \\
\hline $1.5 \% \mathrm{HF}: 9 \% \mathrm{H}_{3} \mathrm{PO}_{4}$ & 10.01 & 15.53 & $55.14 \%$ & 17.73 & $77.12 \%$ \\
\hline $3 \% \mathrm{HBF}_{4}: 12 \% \mathrm{HCOOH}$ & 10.56 & 16.95 & $60.51 \%$ & 17.79 & $68.47 \%$ \\
\hline $3 \% \mathrm{HBF}_{4}: 9 \% \mathrm{HCOOH}$ & 10.44 & 15.58 & $49.23 \%$ & 17.85 & $70.98 \%$ \\
\hline $1.5 \% \mathrm{HBF}_{4}: 9 \% \mathrm{HCOOH}$ & 10.75 & 16.14 & $50.14 \%$ & 17.99 & $67.35 \%$ \\
\hline
\end{tabular}
these combinations the results are in the range of $65 \%$ $70 \%$, while mud acid results are $63 \%$. So, these combinations can also be a part of main acid treatment instead of the mud acid.

Table 1. Porosity results before and after acidizing

The Fig. 1. shows the three curves for the change in the porosity with different combinations used. One combination is $3 \% \mathrm{HF}: 12 \% \mathrm{HCl}$ which is for the comparison, the red one is the 3\% HF: $9 \% \mathrm{H}_{3} \mathrm{PO}_{4}$ which gives the best results and the $3^{\text {rd }}$ one is combination of $3 \% \mathrm{HBF}_{4}$ and $12 \% \mathrm{HCOOH}$. This combination was given priority over $3 \% \mathrm{HBF}_{4}$ and $9 \%$ $\mathrm{HCOOH}$ (although the final results of later combination was better) because it shows good values than the later one before after flush. 


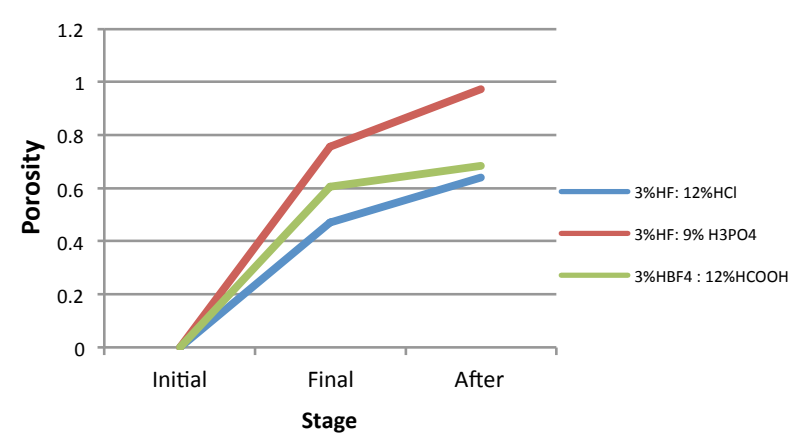

Fig. 1. Comparison of change of porosity between three best combinations

\section{B. Permeability Calculations:}

\section{Analysis:}

- From table \# 2, the change in the permeability in many cases is more than the mud acid. But with the combination $3 \% \mathrm{HF}: 9 \% \mathrm{H}_{3} \mathrm{PO}_{4}$ the permeability change is more and is almost $110 \%$ before after flush. The other concentrations of this combination didn't show better results as compared to mud acid.

- 3\%HF: $9 \% \mathrm{HCOOH}$ also shows much increase in permeability as compared to mud acid and the percentage change is $95 \%$ but the other two concentration of this combination doesn't show good results.

- $3 \% \mathrm{HBF}_{4:} 12 \% \mathrm{HCOOH}$ the permeability change is almost $100 \%$ changed than original. So these combinations can be used as main acid for sandstone acidizing for matrix acidizing, for reservoirs whose initial permeability is less than $100 \mathrm{md}$.

Table 2. Results of permeability before and after acidizing

\begin{tabular}{|c|c|c|c|c|c|}
\hline $\begin{array}{l}\text { Combination } \\
\text { Used }\end{array}$ & $\begin{array}{l}\text { Initial } \\
\text { Permeability }\end{array}$ & $\begin{array}{l}\text { Final } \\
\text { Permeability }\end{array}$ & $\begin{array}{l}\text { \%age } \\
\text { change }\end{array}$ & $\begin{array}{l}\text { Final } \\
\text { Permeability } \\
\text { (After flush) }\end{array}$ & $\begin{array}{l}\begin{array}{l}\% \text { age } \\
\text { change }\end{array}\end{array}$ \\
\hline $\begin{array}{l}3 \% \mathrm{HF}: \\
12 \% \mathrm{HCl} \\
3 \% \mathrm{HF}: \\
12 \% \mathrm{HCOOH} \\
3 \% \mathrm{HF}: \\
9 \% \mathrm{HCOOH} \\
1.5 \% \mathrm{HF}: \\
9 \% \mathrm{HCOOH} \\
3 \% \mathrm{HF}: \\
12 \% \mathrm{H}_{3} \mathrm{PO}_{4} \\
3 \% \mathrm{HF}_{4} \quad 9 \% \\
\mathrm{H}_{3} \mathrm{PO}_{4} \\
1.5 \% \mathrm{HF}: \quad 9 \% \\
\mathrm{H}_{3} \mathrm{PO}_{4} \\
3 \% \mathrm{HBF}_{4} \\
12 \% \mathrm{HCOOH}^{2} \\
3 \% \mathrm{HBF}_{4} \\
9 \% \mathrm{HCOOH}^{2} \\
1.5 \% \mathrm{HBF}_{4}: \\
9 \% \mathrm{HCOOH}^{2}\end{array}$ & $\begin{array}{l}70.26 \\
71.58 \\
74.36 \\
72.25 \\
71.46 \\
70.5 \\
72.89 \\
71.81 \\
71.82 \\
71.78\end{array}$ & $\begin{array}{l}123.876 \\
102.511 \\
145.278 \\
113.474 \\
120.305 \\
148.223 \\
106.868 \\
147.26 \\
145.278 \\
125.17\end{array}$ & $\begin{array}{l}76.31 \% \\
43.21 \% \\
95.37 \% \\
57.06 \% \\
68.35 \% \\
110.25 \% \\
46.62 \% \\
105.07 \% \\
102.28 \% \\
74.38 \% \\
\end{array}$ & $\begin{array}{l}141.76 \\
140.68 \\
163.24 \\
132.58 \\
131.47 \\
165.90 \\
115.29 \\
164.96 \\
162.32 \\
140.25\end{array}$ & $\begin{array}{l}101.76 \% \\
96.54 \% \\
119.53 \% \\
83.50 \% \\
83.98 \% \\
135.32 \% \\
58.17 \% \\
129.72 \% \\
126.01 \% \\
95.39 \% \\
\end{array}$ \\
\hline
\end{tabular}

The Fig. 2. shows the three curves for the change in the permeability with different combinations used. One combination is $3 \% \mathrm{HF}: 12 \% \mathrm{HCl}$ which is for the comparison, the red one is the 3\% HF: $9 \% \mathrm{H}_{3} \mathrm{PO}_{4}$ which gives the best results and the $3^{\text {rd }}$ one is combination of $3 \%$ $\mathrm{HBF}_{4}$ and $12 \% \mathrm{HCOOH}$. Although the results of $3 \% \mathrm{HBF}_{4}$ : $9 \% \mathrm{HCOOH}$ are similar to previous one but due to porosity results preference should be given to $3 \%$ HBF4: $12 \%$ $\mathrm{HCOOH}$

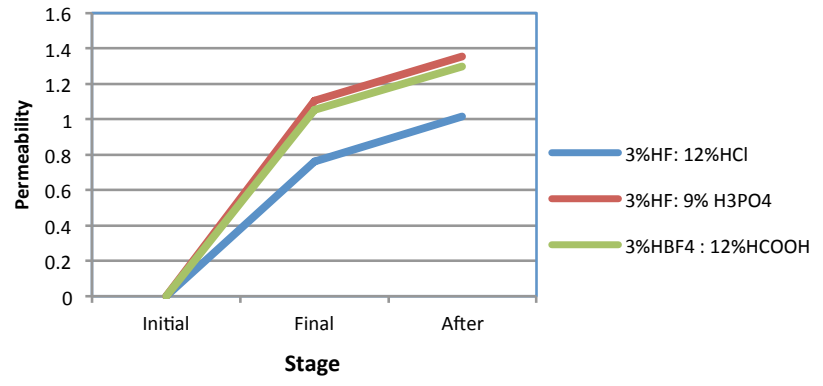

Fig. 2. Comparison of change of permeability between three best combinations

\section{Mineralogy Measurement:}

Field Emission Scanning Electron Microscope (FESEM) was used to check the elemental composition before and after the acidizing.

- Initial Composition: First of all let's see the initial mineralogical composition. It contains almost $56 \%$ oxygen in different forms such as $\mathrm{Al}_{2} \mathrm{O}_{3}, \mathrm{SiO}_{2}$, and Feldspar etc. Second main Component is Silicon which is almost $38 \%$. So in total we can say that $94 \%$ of the sample contains silicon and oxygen. Aluminum, Calcium is also present in large ratio as compared to potassium and Iron.

- $\mathbf{H F}+$ HCl: It dissolves a large quantity of silicon, small quantities of Aluminum and Calcium, but the iron contents has been increased which is the indication of corrosion materials present in it. But a large amount of carbon has been detected which was not present initially. It means that carbonates are dissolved leaving carbon traces behind.

- $\mathbf{H F}+\mathbf{H}_{3} \underline{P O}_{4}$ : It also dissolves amount of silicon but less than mud acid, but in this case there is no carbon found. Traces of phosphorous and fluorine are also found, amount of iron has been decreased.

- HF + HCOOH: It also dissolves amount of silicon but less than mud acid, but in this case there is no carbon found. No Traces of phosphorous and fluorine are also found, amount of iron has been decreased.

- $\mathbf{H B F}_{4}+\mathbf{H C O O H : ~ I t ~ a l s o ~ d i s s o l v e s ~ a m o u n t ~ o f ~ s i l i c o n ~}$ but less than mud acid, but in this case there is no carbon found. Traces of phosphorous and fluorine are also found, amount of iron has been decreased.

\section{Analysis:}

- From table \# 3, Carbon is only present after combination of $\mathrm{HF}+\mathrm{HCl}$, and there is less change in the values of permeability and porosity after this combinations used. Carbon is not present after the other combinations used. It also means those carbon components are a reason for less permeability increase and this carbon is present only after when $\mathrm{HCl}$ is used.

- In all the combinations used except $\left(\mathrm{HF}+\mathrm{H}_{3} \mathrm{PO}_{4}\right)$, one thing is common, which is the increase in the iron component. It means that we need to use corrosion inhibitor during the injection of these acids into the well because they can cause corrosion of the pipes and other things. But in the case of phosphoric acid, the iron component has been decreased which is the opposite as compared to other combinations. It means there is no need of corrosion inhibitor when phosphoric acid has acid has been used as it can itself react as a corrosion inhibitor. 
Table 3. Minerological composition before and after acidizing

\begin{tabular}{|c|c|c|c|c|c|c|}
\hline \multicolumn{2}{|c|}{ Initial composition } & \multirow[b]{2}{*}{$\begin{array}{l}\mathrm{HF} \\
\mathrm{HCl}\end{array}$} & \multirow[b]{2}{*}{$\mathrm{HF}+\mathrm{H}_{3} \mathrm{PO}_{4}$} & \multirow[b]{2}{*}{$\mathrm{HF}+\mathrm{HCOOH}$} & \multirow[b]{2}{*}{$\begin{array}{l}\mathrm{HBF}_{4} \\
\mathrm{HCOOH}\end{array}$} & \\
\hline Elements & $\begin{array}{l}\text { \%age } \\
\text { weight }\end{array}$ & & & & & + \\
\hline $\begin{array}{l}\text { Oxygen } \\
\text { (O) }\end{array}$ & 55.94 & 51.03 & 50.97 & 56.42 & 55.95 & \\
\hline Silicon (Si) & 38.05 & 27.02 & 34.27 & 37.54 & 36.34 & \\
\hline $\begin{array}{l}\text { Aluminum } \\
\text { (Al) }\end{array}$ & 2.95 & 1.89 & 2.49 & 2.08 & 2.30 & \\
\hline $\begin{array}{l}\text { Potassium } \\
\text { (K) }\end{array}$ & 1.00 & 0.90 & 0.86 & 0.75 & 0.95 & \\
\hline Iron $(\mathrm{Fe})$ & 0.96 & 1.28 & 0.78 & 1.79 & 2.36 & \\
\hline $\begin{array}{l}\text { Fluorine } \\
\text { (F) }\end{array}$ & 0 & 0 & 7.28 & 0 & 0 & \\
\hline $\begin{array}{l}\text { Phosphorus } \\
\text { (P) }\end{array}$ & 0 & 0 & 1.12 & 0 & 0 & \\
\hline $\begin{array}{l}\text { Chlorine } \\
\text { (Cl) }\end{array}$ & 0 & 1.17 & 0.87 & 0.85 & 0.96 & \\
\hline $\begin{array}{l}\text { Calcium } \\
\text { (Ca) }\end{array}$ & 2.04 & 0.81 & 1.36 & 0.57 & 1.12 & \\
\hline Carbon (C) & 0 & 15.92 & 0 & 0 & 0 & \\
\hline $\begin{array}{l}\text { Magnesium } \\
\text { (Mg) }\end{array}$ & 0 & 0 & 0 & 0 & 0 & \\
\hline
\end{tabular}

\section{Compressive Strength Calculations:}

From table \# 4 tests results shows clearly that the combination (HF: $\mathrm{H}_{3} \mathrm{PO}_{4}$ ) with which the porosity and permeability change is the maximum; there is also about $25 \%$ change in strength. But the strength change with mud acid is also same but in that case the porosity permeability change is less as compared to that acid. This may be due to the reason that precipitate may form due to very fast reaction of the HF acid. This also shows that the action of $\mathrm{H}_{3} \mathrm{PO}_{4}$ as a buffer solution is very effective and also better than $\mathrm{HCl}$ acid. But with the combination of $\mathrm{HBF}_{4}$ : $\mathrm{HCOOH}(3: 12)$, the change is maximum and with this combination permeability and porosity change is also high which means that this acid although changes porosity and permeability but meanwhile it is weakening the rock by dissolving the components. With the other combination having good results, the strength change is also the maximum.
Table 4. Results of compressive strength permeability before and after acidizing

\begin{tabular}{|c|c|c|c|c|c|c|}
\hline $\begin{array}{l}\text { Combination } \\
\text { used }\end{array}$ & $\begin{array}{l}\text { Initial } \\
\text { Peak } \\
\text { Load } \\
\end{array}$ & $\begin{array}{l}\text { Final } \\
\text { Peak } \\
\text { Load }\end{array}$ & $\begin{array}{l}\text { \%age } \\
\text { change }\end{array}$ & $\begin{array}{l}\text { Initial } \\
\text { stress }\end{array}$ & $\begin{array}{l}\text { Final } \\
\text { Stress }\end{array}$ & $\begin{array}{l}\text { \%age } \\
\text { Change }\end{array}$ \\
\hline $\begin{array}{ll}\mathrm{HF}: \mathrm{HCl}(3: 12) \\
\text { HF: } & \mathrm{H}_{3} \mathrm{PO}_{4} \\
(3: 12) & \\
\mathrm{HF}: & \mathrm{H}_{3} \mathrm{PO}_{4} \\
(3: 9) & \\
\mathrm{HF}: & \mathrm{H}_{3} \mathrm{PO}_{4} \\
(1.5: 9) & \\
\mathrm{HBF}_{4}: & \mathrm{HCOOH} \\
(3: 12) & \\
\mathrm{HBF}_{4}: & \mathrm{HCOOH} \\
(3: 9) & \\
\mathrm{HBF}_{4}: & \mathrm{HCOOH} \\
(1.5: 9) \\
\mathrm{HF}: & \mathrm{HCOOH} \\
(3: 12) & \\
\mathrm{HF}: & \mathrm{HCOOH} \\
(3: 9) & \\
\mathrm{HF}: & \mathrm{HCOOH} \\
(1.5: 9) & \\
\end{array}$ & \begin{tabular}{l|}
53.1 \\
53.1 \\
53.1 \\
53.1 \\
53.1 \\
53.1 \\
53.1 \\
53.1 \\
53.1 \\
53.1
\end{tabular} & \begin{tabular}{l|}
39.6 \\
42.7 \\
39.5 \\
41.7 \\
33.7 \\
38.4 \\
47.7 \\
45.9 \\
36.5 \\
45.0
\end{tabular} & $\begin{array}{l}-25.42 \% \\
-19.59 \% \\
-25.61 \% \\
-21.47 \% \\
-36.54 \% \\
-27.68 \% \\
-10.17 \% \\
-13.56 \% \\
-31.26 \% \\
-15.25 \%\end{array}$ & \begin{tabular}{l|l|}
55.15 \\
55.15 \\
\\
55.15 \\
\\
55.15 \\
55.15 \\
55.15 \\
55.15 \\
55.15 \\
55.15 \\
55.15
\end{tabular} & $\begin{array}{l}41.4 \\
44.4 \\
41.2 \\
43.4 \\
35.2 \\
41.1 \\
49.5 \\
47.75 \\
38.2 \\
46.81\end{array}$ & $\begin{array}{l}-24.93 \% \\
-19.49 \% \\
-25.30 \% \\
-21.31 \% \\
-36.17 \% \\
-25.48 \% \\
-10.25 \% \\
-13.42 \% \\
-30.73 \% \\
-15.12 \%\end{array}$ \\
\hline
\end{tabular}

\section{Conclusion:}

\section{- Orthophosphoric Acid has two Advantages over HCl:}

$>$ Deep penetration into the formation can be achieved

$>$ Corrosion inhibitors are not required

\section{- Comparison to HCl}

$\mathrm{HCl}$ is particularly corrosive to steel, aluminum or chromium plated equipment which are components of many pumps. Expensive corrosion inhibitors need to be used in these circumstances. This cost becomes very significant when treating formations at higher temperatures due to the requirement for higher doses of corrosion inhibitor. Corrosion inhibitors are not required with Orthophosphoric Acid. It can be seen in the mineralogy tests.

- Also there is no carbon detected when Orthophosphoric acid and formic acid are used, it is present when $\mathrm{HCl}$ is used and there is a less increase in the permeability and porosity values when $\mathrm{HCl}$ is present.

- All the results calculated and observed, it can be said that we can also use combinations of (Hydrofluoric and phosphoric acid) and (Fluoboric and Formic Acid) as a main acid in sandstone acidizing.

\section{References}

1. Muecke, T.W.: "Principles of Acid Stimulation", Paper SPE 10038, the Int. Petroleum Exhb. And Tech. Sym. Of the SPE, Beijing, China, March 18-26, 1982

2. Zeit Bay' "Stimulation of Sandstone Reservoirs", 2005 SPE Technology Transfer Workshop (TTW)

3. Gidley, J.L.: "Stimulation of Sandstone Formations With the AcidMutual Solvent Method", SPE\# 3007, JPT, May 1971, 551-558.

4. Smith, C.F. and Hendrickson, A.R.: "Hydrofluoric Acid Stimulation of Sandstone Reservoirs", Paper SPE 980, February 1965.

5. Eduardo Ponse da Motta and Benjamin Plavnik," Optimizing Sandstone Acidizing", SPE 19426, Petrobras R \& D Center, and R, S. Schechter., Feb 1992.
6. Hill, A.D., Lindsay, D.M., Silberberg, I.H., and Schechter, R.S., "Theoretical and Experimental Studies of Sandstone Acidizing", Paper SPE 6607, SPEJ, Feb. 1982.

7. R. L. Thomas, "The Impact of $\mathrm{HCl}$ to $\mathrm{HF}$ Ratio on Hydrated Silica Formation During the Acidizing of a high temperature Sandstone Gas Reservoir in Saudi Arabia,” SPE 77370, Oct 2002.

8. Gary D. Sutton, R. M. Lasater, "Aspects of Acid Additive Selection in Sandstone Acidizing", SPE 4114.

9. Arcasolve Technical Document ATD-B1, Acidizing oil and gas reservoirs: Current practice and applications of the Arcasolve Acidizing Process 